\title{
A escrita em bandos atribuídos a Rodrigo Cesar de Menezes - governador e capitão general da capitania de São Paulo (1721-1728)
}

\section{The writing in bandos assigned to Rodrigo Cesar de Menezes - General Governor and Captain of the captaincy of São Paulo (1721-1728)}

Phablo Roberto Marchis Fachin

Universidade de São Paulo, São Paulo, SP / Brasil

phablo@usp.br

Gabriela Lubascher Miragaia

Universidade de São Paulo, São Paulo, SP / Brasil

gabriela.miragaia@usp.br

Resumo: O artigo apresenta os resultados de estudo sobre práticas de escrita administrativa em manuscritos produzidos ao longo do século XVIII, no Brasil colonial, especificamente na capitania de São Paulo, durante o governo de Rodrigo Cesar de Menezes (1721-1728). Trata-se, com base em dados documentais e metodologia filológica, da utilização de manuscritos com rigor científico. A importância do estudo reside no fato de que há escassez de informações a respeito do processo de produção documental no Brasil colonial, assim como da sua circulação e difusão. Cabe destacar também que, além dos aspectos relacionados à escrita em bandos setecentistas, a pesquisa também traz contribuição para a história social da capitania de São Paulo, uma vez que, ao levantar os destinatários dos documentos e a sua temática, traz à luz as ordens e a quem se referiam, possibilitando ampliar o estudo realizado com o intuito de entender a lógica administrativa, a composição e organização da sociedade da época.

Palavras-chave: história da língua portuguesa; Rodrigo Cesar de Menezes; edição de manuscritos coloniais. 
Abstract: This article presents the results of study on administrative writing practices in manuscripts produced during the eighteenth century, in colonial Brazil, specifically in the province of São Paulo, during the government of Rodrigo Cesar de Menezes (1721-1728). It is presented, based on documentary evidence, discussion on the use of manuscripts with scientific certainty. The importance of research lies in the fact that there is limited information about the document production process in colonial Brazil, as well as their circulation and diffusion. It is worth mentioning that in addition to aspects related to writing, the survey also brings contribution to the social history of the captaincy of São Paulo, since, to raise the addressees of the document and its thematic, brings to light the orders and to whom it was related, allowing expand the study in order to understand the administrative logic and how they composed and organized the society of the time.

Keywords: history of the portuguese language; Rodrigo Cesar de Menezes; edition of colonial manuscripts.

Recebido em 24 de junho de 2016. Aprovado em 13 de janeiro de 2017.

\section{Introdução}

O estudo da língua portuguesa e da sua história com base em fontes manuscritas apresenta duas características primordiais: por um lado, por se tratar de trabalho que tem como base o levantamento de dados linguísticos concretos, extraídos de documentos manuscritos, na maioria das vezes heterogêneos, de diversas épocas da sua história, pratica-se o estudo das transformações pelas quais a língua passou ao longo de sua trajetória sócio-histórico-cultural, documentando-as; por outro, na medida em que se vai às fontes, realiza-se importante função do trabalho filológico, de acordo com Spina (1994, p. 82), a transcendente ,"em que o texto deixa de ser um fim em si mesmo da tarefa filológica para se transformar num instrumento que permite ao filólogo reconstituir a vida espiritual de um povo ou de uma comunidade em determinada época".

Tarefa nem um pouco simples. Além de complexa, muito morosa, dependente de paciência e persistência do filólogo na busca da documentação necessária ao seu estudo, criteriosa e de muito rigor na 
realização da edição que conserva o estado de língua testemunhado pelo manuscrito. A afirmação de Castro reforça essa assertiva:

Para o linguista usufruir das reais vantagens do texto não-literário, que lhe permitem saber como uma pessoa identificada escrevia (e talvez falasse) em determinado ponto do tempo e do espaço, precisa de se inteirar primeiro das circunstâncias históricas em que o texto foi escrito. É esse o campo de intervenção de uma série de disciplinas auxiliares da História e da Filologia, equipadas com metodologias próprias que podem atingir apreciável sofisticação - a paleografia, a diplomática e a codicologia, antes de mais, mas a crítica textual também (CASTRO, 2004, p. 3).

Nesse contexto de busca e edição de manuscritos para a realização de estudos sobre a história da língua portuguesa, o pesquisador depara com documentos de naturezas diversas, originais, textos autógrafos, cópias, textos apógrafos, ideógrafos, vias, entre outros. Em meio a esse leque de opções, precisa lançar mão de mecanismos que garantam a fidedignidade do texto e o conhecimento real de sua história. Não se trata apenas de um trabalho técnico de leitura e transcrição, adequação de um texto manuscrito, em letra antiga, muitas vezes de difícil decifração, para caracteres tipográficos, ao alcance de um público mais amplo. Trata-se de um trabalho que leva o filólogo a conhecer o documento, a sua história, todas as implicações relacionadas ao seu corpo, conteúdo, hábitos gráficos, estilo e autoria, principalmente autoria. ${ }^{1}$ Nas palavras de Fachin,

relativamente à tradição documental, a necessária distinção entre original e cópia nem sempre é isenta de questões. [...]. No caso das práticas administrativas coloniais, era muito comum a autoridade superior apenas assinar o documento enquanto secretários, escrivães e outros profissionais da escrita os escreviam. Dessa forma, estudos que não levam

\footnotetext{
1 "Nesse contexto, várias possibilidades estão em jogo: manuscritos escritos pela mão do próprio autor (autor material e intelectual); acompanhados pelo autor intelectual, mas pela mão de terceiros (autores materiais); reproduzidos, mais ou menos integralmente, por cópias. Consequentemente, nem sempre a datação, assim como a assinatura do documento e os dados gráficos ali presentes, correspondiam realmente ao seu contexto de produção". (FACHIN, 2014, p. 221)
} 
isso em consideração acabam resultando em atribuição equivocada de autoria documental (FACHIN, 2014, p. 222).

Levando esses fatos em consideração, apresentam-se, neste artigo, os resultados de estudo sobre práticas de escrita administrativas em manuscritos produzidos ao longo do século XVIII, no Brasil colonial, especificamente na capitania de São Paulo. O corpus consta de bandos produzidos por Gervasio Leyte Rebello, secretário do governador e capitão general Rodrigo Cesar de Menezes, cuja autoria é atribuída a este, embora materialmente tenham sido escritos por aquele, fato que pode ter influência no resultado gráfico do documento e, por essa razão, é de suma importância para pesquisas que tenham como objetivo estudos linguísticos do período.

Trata-se de cuidado metodológico que deve ser levado em consideração para evitar resultados equivocados por conta da falta de critérios no tratamento das fontes. Veja-se, por exemplo, o caso da Publicação Official de Documentos Interessantes para a História e Costumes de São Paulo correspondência interna do Governador Rodrigo Cesar de Menezes ---1721-1728. Na edição dos documentos que compõem a obra, ao final sempre aparece a indicação do nome do governador em itálico, como uma espécie de assinatura, atribuindo a ele, de certa forma, a autoria dos textos. Ao observar, porém, originais manuscritos desses documentos, verifica-se que, embora a assinatura faça parte de quase todos eles, a caligrafia do resto do texto não é a mesma, apresentando-se com diferentes formas, o que indica diferença de punhos; portanto outras pessoas foram as responsáveis pela sua produção material. Consequentemente havia diversidade de hábitos e escolhas gráficas, principalmente num período em que a escrita apresentava pluralismos gráficos (FACHIN, 2014, p. 222).

$\mathrm{O}$ artigo também tem como objetivo apresentar discussão, com base em dados documentais e metodologia filológica, sobre a utilização de manuscritos com rigor científico. A importância do estudo reside no fato de que há escassez de informações a respeito do processo de produção documental no Brasil colonial, assim como da sua circulação e difusão. Embora se observe que é crescente o número de edições com ressaltado rigor na busca de exatidão e fidelidade, esse aspecto ainda carece de 
cuidado filológico. Os trabalhos no campo da Filologia e ciências afins, com "tendência nitidamente marcada pela preocupação em não se deixar perder nenhum dos traços da fonte primária no ato de transcrição, diria mais: mesmo as anotações à margem ou nas entrelinhas, bem como informações consideradas alheias ao conteúdo do texto" (MEGALE, 1998 , p. 3), também devem levar em conta o contexto de produção dos documentos selecionados para o trabalho, assim como a sua forma de transmissão e circulação. Portanto, em meio a esse contexto, a falta de cautela no tratamento das fontes, por conta da ausência de critérios ou do desconhecimento das circunstâncias de produção, pode acarretar problemas sérios de interpretação filológica e linguística.

Cabe ainda destacar que, além dos aspectos relacionados à escrita, o estudo contribui para a história social da capitania de São Paulo, onde os documentos foram escritos. Ao levantar os destinatários dos documentos e a sua temática, traz à luz as ordens e a quem se referiam, possibilitando ampliar a pesquisa realizada, com o intuito de entender a lógica administrativa, a composição e organização da sociedade da época. Como exemplo, verifica-se o comportamento dos escravos quanto a jogos; de religiosos, quanto ao seu dia a dia, como também em relação aos índios e seus costumes.

\section{Metodologia}

Este artigo tem caráter filológico e apresenta metodologia cuja base é ir às fontes e ao estudo do texto (MEGALE, 1998). Além de levar em consideração a explicação dos testemunhos e de sua história, preocupa-se com problemas de outra ordem, que não estão neles, "mas se deduzem deles: a sua autoria, a sua datação e a sua importância (valorização) perante os textos da mesma natureza" (SPINA, 1994, p. 76). Para isso, o seu plano de trabalho foi composto por 5 etapas: 1) levantamento dos cargos da administração colonial ligados à prática de escrita do século XVIII, na capitania de São Paulo; 2) levantamento dos correspondentes envolvidos na documentação que compõem o corpus; 3) comparação dos dados levantados com o intuito de identificar o contexto de produção e circulação dos documentos; 4) análise das assinaturas e o tipo de letra dos documentos para identificar questões de autoria; 5) verificação, com base nas etapas anteriores, do quanto esses fatores poderiam auxiliar no estudo das práticas de escrita setecentista no contexto administrativo colonial. 
Para a realização da primeira etapa do trabalho, levantamento dos cargos da administração colonial ligados à prática de escrita no século XVIII, na capitania de São Paulo, utilizou-se, além dos documentos que compõem o corpus do projeto, o livro Fiscais e meirinhos - a administração no Brasil colonial, coordenado por Salgado (1985). Os dados identificados foram distribuídos em tabela para melhor visualização, organizados da seguinte maneira: cargo, página, termo ou expressão relacionado à escrita. Posteriormente, foram comparados com os encontrados nos manuscritos para verificar as suas compatibilidades.

O resultado da segunda etapa do plano de trabalho - levantamento dos correspondentes envolvidos na documentação que compõe o corpus - também foi organizado em tabela, com a seguinte ordem: datação, destinatário, cargo do destinatário, autor material, cargo do autor material, assinatura, cargo de quem assinou o documento, autor intelectual e cargo do autor intelectual. Essa tabela é baseada no corpus do estudo Bandos - encontrados nos volumes XII, XIII e XXXII dos Documentos Interessantes. A terceira etapa - comparação dos dados coletados com o intuito de identificar o contexto de produção e circulação dos documentos - foi realizada cotejando-se os dados das duas tabelas das etapas anteriores a fim de identificar o contexto de produção e circulação dos documentos. Com base nesses resultados, realizaram-se as duas últimas: 4) análise das assinaturas e caligrafias dos documentos para identificar questões de autoria; 5) verificação, com base nas etapas anteriores do quanto esses fatores poderiam auxiliar no estudo das práticas de escrita dos escribas da época.

\section{0 corpus e suas implicações}

O corpus está composto de uma tipologia documental denominada bando, que cobre todo o período do governo de Rodrigo Cesar de Menezes (1721-1728). Ao todo são 86 documentos, localizados no Arquivo Público do Estado de São Paulo. Como exemplos, seguem (FIG.1 e 2) as imagens de documento escrito em São Paulo em 18 de setembro de 1721, com autoria intelectual atribuída a Rodrigo Cesar de Menezes e material de Gervasio Leyte Rebello. Trata-se da versão manuscrita que consta de livro de registro do Arquivo Público do Estado de São Paulo e da versão impressa encontrada no volume XII dos Documentos Interessantes para a história e costumes de São Paulo (APESP, 1901). Acompanha também a lição transcrita do documento, com indicação das diferenças entre as versões. 
FIGURA 1 - Fac-símile do bando (versão manuscrita) encontrado no Arquivo Público do Estado de São Paulo. Caixa 48. Ordem 406.
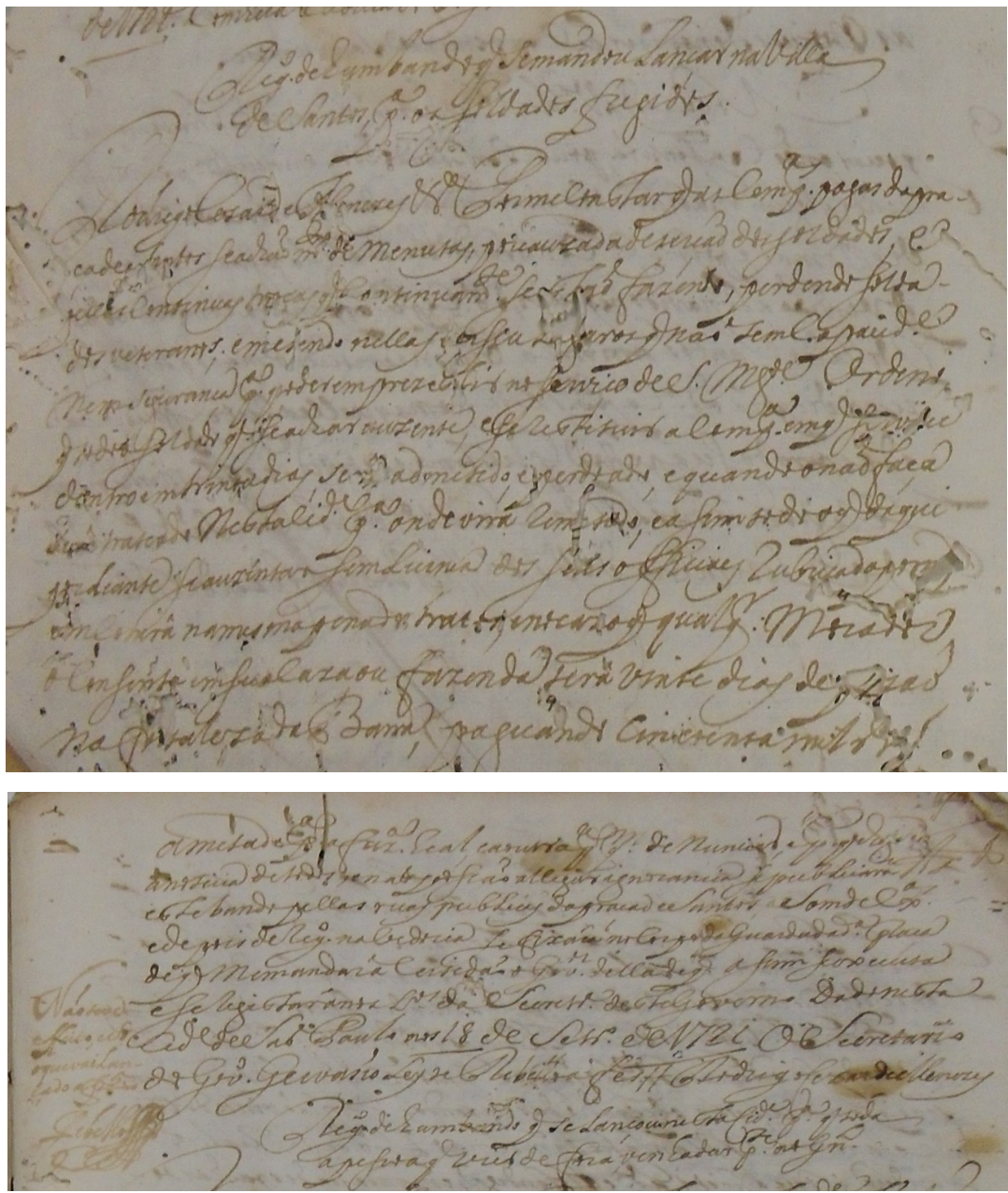

Fonte: APESP, 1901. 
FIGURA 2 - Fac-símile do bando (versão impressa) encontrado no Arquivo Público do Estado de São Paulo. Caixa 48. Ordem 406.

\section{Reg. ${ }^{\circ}$ de hum bando q' se mandou lançar na Villa de Santos. p. os Soldados fugidos.}

Rodrigo Cezar de Menezes, etc.-Por me constar que as companhias pagas da praça de Santos se acháo m..$^{10}$ demenutas, por cauza da dezerção dos soldados e pellas continuas trocas q' continuam. ${ }^{\text {to }}$ se estáo fezendo, perdendo soldados veteranos; e metendo nellas em seu lugar os q' não tem capacid." nem segurança p. ${ }^{\mathrm{a}}$ poderem prezestir no serviço de S. Mag.de : ordeno q' todo o soldado q' se achar auzente, e se restituir a comp." em q. serviu dentro em trinta dias, serâ admetido, e perdoado, e quando o não faça serâ trancalo nesta cid. ${ }^{e}$ p. $^{2}$ onde virâ remetido, e assim todo 0 q' daqui por diante se auzentar sem Licença dos seus officiaes rubricada por my, emeorrerì na mesma pena dos tratos, e no caso q' qualq. morador 0 consinta em sua casa ou fazenda terâ vinte clias de prizão na fortaleza da Barra, paguando cincoenta mil $r s .-$ a metade $p .^{a}$ a faz.. ${ }^{\mathrm{a}}$ real, e a outra p. $^{\mathrm{a}} \mathrm{q}^{\mathrm{m}}$ denunciar, e p." q' chegue a noticia de todos, e não possão allegar ignorancia se publicarâ este bando pellas ruas publicas da praça de Santos, a som de $\mathrm{ex}^{.{ }^{\text {ns }}} \mathrm{e}$ depois de reg.. ${ }^{\circ}$ na vedoria se fixarão no corpo da Guarda da d.a praça de q' me mandarâ certidão 0 Gov. ${ }^{{ }^{r} r}$ della de q' assim se executa e se registrará nos L. ${ }^{\text {os }}$ da Secretr. ${ }^{a}$ deste Governo. Dado nesta cid. ${ }^{\circ}$ de S. Paulo aos 18 de Setr. ${ }^{\circ}$ de 1721. 0 Secretario do Gov. ${ }^{0}$ Gervasio Leyte Rebello a fez. - Rodrigo Cezar de Menceses.

- Nota - Não teve efleito, e só o q' vae Lançado a fls. 5-Rebello.

Fonte: APESP, 1901. 
Transcrição conservadora do bando, realizada de acordo com o manuscrito, sem qualquer tipo de acréscimo, respeitando o estado de língua do documento, inclusive as abreviaturas, a ordenação das linhas e a fronteira de palavras:
Reg $^{\circ}$.dehumbandoqSemandouLançar naVilla deSantos, $\mathrm{p}^{\mathrm{a}}$ ossoldados fugidos
RodrigoCezardeMenezes etcPormeconstarqasComp. as pagas dapra- çadeSantos seachaõ m. ${ }^{\text {to }}$ demenutas, porcauzadadeserçaõ dossoldados, e pellasContinuas trocas qContinuam ${ }^{\text {te }}$ seestaõfazendo, perdendosolda- dos veteranos; emetendo nellas eenseuLugarosqnaõ temCapacid. ${ }^{e}$ nemSegurança $p .{ }^{a}$ poderemprezestir noserviço deS.Mag. ${ }^{\text {de }}$ Ordeno qtodoosoldado qseachar auzente, eserestituir aCompa.emqserviu dentro emtrintadias, serâ admetido, eperdoado, equandoonaõfaça será trateado NestaCid. ${ }^{\mathrm{e}}$ p. ${ }^{\mathrm{a}}$ onde virâ remetido, easim todooqdaqui pordiante seauzentarsemLicença dos seus officiaes rubricadapormy emCorrerâ namesmapenados tratos, enocazoqqualq': morador oConsinta emsuaCaza ou fazenda terá vinte dias deprizaõ nafortalezadaBarra, paguando Cincoentamil rs ametade p. ${ }^{\mathrm{a} a f a z} .{ }^{\mathrm{a}}$ real, eaoutrap. ${ }^{\mathrm{a}} \mathrm{q} .{ }^{\mathrm{m}}$ deNunciar, ep ${ }^{\mathrm{a}} \mathrm{qch}$ egue anoticia detodos, enaõpossaõ allegar ignorancia sepublicarâ estebandopellas ruas publicas dapraçadeSantos, aSomdeCx. ${ }^{\text {as }}$ edepois deReg. ${ }^{\circ}$ navedoria sefixarâ noCorpodaGuardadad. ${ }^{a}$ praça deqMemandarâCertidaõ oGov. ${ }^{\text {or }}$ delladeq asim seexecuta eseregistraránosL ${ }^{\text {os }}$ daSecretr. ${ }^{a}$ desteGoverno Dadonesta

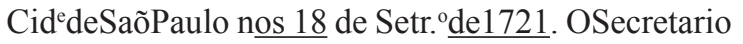 doGov. ${ }^{\circ}$ Gervasío LeyteRebelloafes// RodrigoCezardeMenezes

O cotejo entre as versões impressa e manuscrita revela diferenças nos seguintes aspectos: troca de palavras, pontuação, fronteira de palavras e, às vezes, acréscimo de marcas não presentes no documento. Seguem alguns exemplos: 
TABELA 1 - Comparação de alguns casos entre as versões manuscrita e impressa do bando.

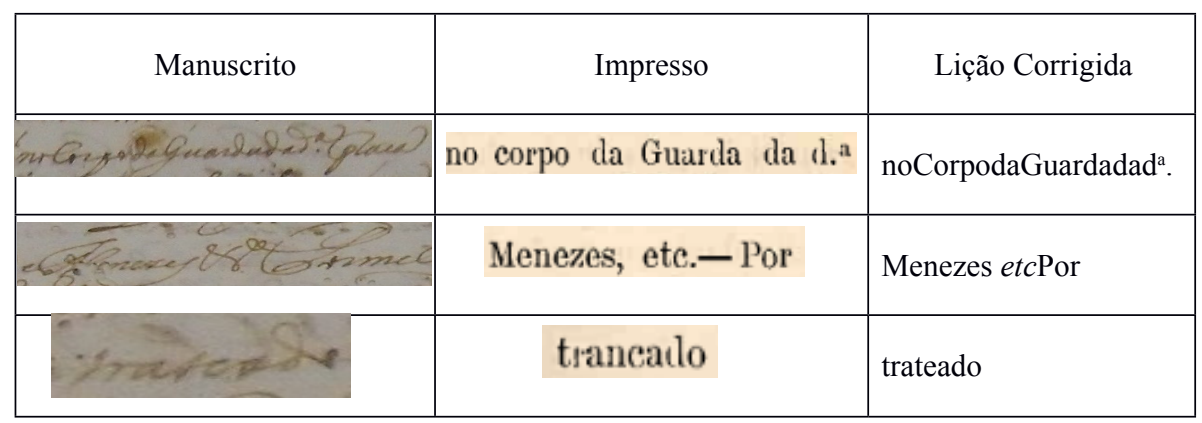

Fonte: Documentos que compõem o corpus da pesquisa realizada.

O fato de se constatarem equívocos de leitura da versão impressa e de haver uma versão manuscrita (presente em livro de registro de cópias) do documento não possibilita a exclusão da impressa, uma vez que não se determinou ainda se a manuscrita serviu de base para a primeira, o que sugere pensar que ambas as versões podem contribuir para o estudo da escrita do Governo de Rodrigo Cesar de Menezes.

Em relação à espécie documental bando, de acordo com Bellotto (2002, p. 50-51), apresenta a seguinte estrutura: 'Protocolo inicial: nome e qualificação do autor (autoridade delegada). Texto: a ordem objeto do bando. Protocolo final: datas tópica e cronológica. Subscrição com o nome do autor". Pela análise, o texto é composto de uma justificativa da razão do bando e da sua ordem e o protocolo final, da advertência sobre a sua divulgação e o encerramento com as datações. Essa estrutura pode ser observada pela tabela que segue. 
TABELA 2 - Estrutura padrão do bando aos soldados fugitivos do volume XII dos Documentos Interessantes.

\begin{tabular}{|c|c|}
\hline \multirow[t]{2}{*}{$\begin{array}{l}\text { Protocolo } \\
\text { Inicial }\end{array}$} & $\begin{array}{l}\text { Reg }{ }^{\circ} \text { dehumbandoqSemandouLançar naVilla } \\
\text { deSantos, } p^{\text {a }} \text { ossoldados fugidos }\end{array}$ \\
\hline & RodrigoCezardeMenezes etc \\
\hline \multirow[t]{3}{*}{ Texto } & $\begin{array}{l}\text { PormeconstarqasComp. }{ }^{\text {as }} \text { pagas dapra- } \\
\text { çadeSantos seachaõ m. } .^{\text {to }} \text { demenutas, porcauzadadeserçaõ dossoldados, e } \\
\text { pellasContinuas trocas qContinuam }{ }^{\text {te }} \text { seestaõfazendo, perdendosolda- } \\
\text { dos veteranos; emetendo nellas eenseuLugarosqnaõ temCapacid. }{ }^{\text {e }} \\
\text { nemSegurança p. }{ }^{\text {a }} \text { poderemprezestir noserviço deS.Mag. }{ }^{\text {de }}\end{array}$ \\
\hline & Ordeno \\
\hline & $\begin{array}{l}\text { qtodoosoldado qseachar auzente, eserestituir aComp }{ }^{\mathrm{a}} \text {.emqserviu } \\
\text { dentro emtrintadias, serâ admetido, eperdoado, equandoonaõfaça } \\
\text { será trateado NestaCid. }{ }^{\mathrm{e}} \text { p. }{ }^{\mathrm{a}} \text { onde virâ remetido, easim todooqdaqui } \\
\text { pordiante seauzentarsemLicença dos seus officiaes rubricadapormy } \\
\text { emCorrerâ namesmapenados tratos, enocazoqqualq⿳: morador } \\
\text { oConsinta emsuaCaza ou fazenda terá vinte dias deprizaõ } \\
\text { nafortalezadaBarra, paguando Cincoentamil rs } \\
\text { ametade p. }{ }^{\mathrm{a} a f a z .} .^{\mathrm{a}} \text { real, eaoutrap. }{ }^{\mathrm{a}} \mathrm{q} .{ }^{\mathrm{m}} \text { deNunciar, }\end{array}$ \\
\hline \multirow[t]{3}{*}{$\begin{array}{l}\text { Protocolo } \\
\text { Final }\end{array}$} & $\begin{array}{l}\text { ep }{ }^{\text {a }} \text { qchegue } \\
\text { anoticia detodos, enaõpossaõ allegar ignorancia sepublicarâ } \\
\text { estebandopellas ruas publicas dapraçadeSantos, aSomdeCx. }{ }^{\text {as }} \\
\text { edepois deReg. }{ }^{\circ} \text { navedoria sefixarâ noCorpodaGuardadad. }{ }^{\text {a }} \text { praça } \\
\text { deqMemandarâCertidaõ oGov. }{ }^{\text {or }} \text { delladeq asim seexecuta } \\
\text { eseregistraránosL }{ }^{\text {os }} \text { daSecretr. }{ }^{\text {a }} \text { desteGoverno }\end{array}$ \\
\hline & Dadonesta CidedeSaõPaulo aos 18 de Setr. ${ }^{\circ} \underline{\text { de } 1721}$. \\
\hline & OSecretario doGovº. Gervasío LeyteRebelloafes// RodrigoCezardeMenezes \\
\hline
\end{tabular}

Fonte: APESP, 1901, p. 9.

Por se tratar de documento diplomático lavrado em contexto administrativo, o bando mantém sua estrutura em todo o corpus. Isso ocorre mesmo diante de diferentes destinatários. No caso analisado, consideram-se índios, proprietários de índios, negros e seus proprietários, soldados, outros tipos de pessoas, além de religiosos. A variação gráfica encontrada, portanto, não teria influência desse aspecto diplomático. As suas particularidades estão relacionadas possivelmente à prática de escrita do escriba ou da tradição administrativa em questão. A estrutura padrão 
e a sua autoria material limitada a um número reduzido de autores, no entanto, não garantem a regularidade gráfica da escrita do corpus, fato demonstrado pela análise gráfica realizada. Ao longo do corpus, em bandos datados para os anos de 1721 - 1728, pode-se verificar variações de ordens diversas.

$\mathrm{Na}$ época em que foram produzidos, a Administração Colonial era composta de diversos setores. Para sua governança, a produção de documentos ocupava um papel de destaque, uma vez que, por meio dela, leis e outras ordens chegavam a diversos destinatários, independentemente do setor, ultrapassando obstáculos ambientais da natureza colonial. Muitas vezes, determinados documentos eram produzidos para outro tipo de destinatário, isto é, para aqueles que não estavam na esfera administrativa ou por algum motivo se encontravam afastados dela. Nesse contexto, o documento intitulado bando se destacava por sua funcionalidade e alcance público, como pode ser observado na descrição tipológica de Bellotto.

Ocorre apenas na administração colonial. É a ordem ou o decreto, em geral, dos governadores e capitães generais, proclamada $(\mathrm{o})$ oralmente em pregão público ou afixada(o) em lugar ou veículo de circulação pública. $\mathrm{O}$ mesmo que édito ou mandato proibitório. Era utilizada(o) para questões cotidianas relacionadas ao cumprimento de ordens pontuais. Muitas vezes, funcionava como documento de correspondência, isto é, para que se cumprisse em jurisdição mais limitada, uma ordem mais ampla de origem superior (BELLOTTO, 2002, p. 50-51).

A importância desse documento para a administração colonial pode ser constatada pela frequência com que era produzido e pelos destinatários a que se referia. Em oito anos de governo, foram encontrados oitenta e seis bandos nos documentos que compõem o corpus, sem contar os testemunhos perdidos que não constam das obras levantadas. Em média, a sua produção era mensal, e ordens pontuais faziam parte do contexto administrativo. Entre os seus destinatários, estavam todas as camadas que compunham aquela sociedade setecentista, como soldados, religiosos, donos de negros e índios e forasteiros.

Nos volumes XII e XIII dos Documentos Interessantes, verificouse que os remetentes eram o Secretário do Governador, Gervasio Leyte Rebello, e o próprio Governador e Capitão General, Rodrigo Cesar de 
Menezes. Isso se deve ao fato de que esses volumes tratam especificamente dos Bandos e Portarias de Rodrigo Cesar de Menezes. Já no volume XXXII da publicação do APESP, Correspondências e Papéis Avulsos de Rodrigo Cesar de Menezes, havia outros cargos também ligados a remetentes, tais como Capitães (por exemplo: Capitão-Mor, Capitão Geral, Capitão General), Ouvidores e Governadores de outras capitanias. Entre os destinatários encontrados nos bandos que compõem o corpus, há Soldados, Índios, Negros, as Minas de Cuiabá, Postos de Guerra e Auxiliares, Companhia da Ordenança e Auxiliares, Forasteiros e Pessoas no geral. Ao analisar o mesmo fator no livro Fiscais e Meirinhos - a administração no Brasil Colonial, sob coordenação de Salgado (1985), ${ }^{2}$ encontrou-se uma variedade de cargos que exerciam fortemente essa função, tais como Juízes ( Juízes Ordinários, Juízes dos Órfãos, Juízes de Alfândega, Juiz dos Feitos da Coroa, entre outros), Ouvidores ( Ouvidor Geral do Cível, Ouvidor Geral do Crime, Ouvidor de Capitania, entre outros), Provedores ( Provedor e Escrivão do Registro, Provedor dos Feitos da Coroa, Provedor da Minas, entre outros) e, principalmente, Escrivães.

A grande diversidade de destinatários dos bandos se deve ao fato de que esse tipo de correspondência era a própria ordem ou decreto. A frequente ocorrência de seus relatos no livro de Washington Luís, Capitania de São Paulo - Governo de Rodrigo Cesar de Menezes, mostra-nos a importância e a relevância para a Administração Colonial desse documento. Exemplo disso, no volume XXXII, é representado pela contenda entre o governador e os famosos irmãos Lemes, figuras importantes desse governo, mortos a mando de Menezes, o qual ordenou a fixação de um bando, dizendo que todo aquele que ajudasse a capturar os Lemes, vivos ou mortos, seria beneficiado, mas todo aquele que os ajudasse a se salvar pagaria o preço. Observa-se que, por meio de um documento, o governador acabou por colocar a capitania inteira de São Paulo contra os irmãos, sob pena de traição à coroa, confisco de bens e mais penas que, em semelhantes casos, eram impostas, infundindo uma espécie de "regime do terror". Isso fazia as pessoas se sentirem livres para cometer crimes, inclusive os escravos, caso viessem a matar seus senhores, pois, se pegassem os irmãos Lemes, estariam salvos pelo crime cometido.

\footnotetext{
${ }^{2}$ Obra com relação sistemática de cargos e órgãos da política administrativa do Brasil colonial.
} 


\section{Abaixo segue tabela com a indicação dos bandos que compõem} o corpus do estudo, com a informação sobre a razão de terem sido produzidos.

\section{TABELA 3 - Lista com todos os bandos do corpus}

\begin{tabular}{|c|c|}
\hline \multicolumn{2}{|r|}{ Volume XII } \\
\hline Datação & Temática \\
\hline 1721, Setembro 18 & bando que se mandou lançar na Vila de Santos para os soldados fugidos \\
\hline 1721, Setembro 21 & $\begin{array}{l}\text { bando que se lançou nesta cidade para que toda pessoa que vier de fora venha } \\
\text { dar parte ao General }\end{array}$ \\
\hline 1721, Outubro 7 & $\begin{array}{l}\text { bando que se lançou nesta cidade para se quintar o ouro que também se lançou } \\
\text { em Santos, Itu e Sorocaba }\end{array}$ \\
\hline 1721, Outubro 8 & $\begin{array}{l}\text { bando sobre os Soldados da Praça de Santos que andam fugidos e índios desta } \\
\text { cidade que andam ausentes }\end{array}$ \\
\hline 1721, Outubro 9 & bando para os Índios que estiverem fora de suas aldeias serem repostos nelas \\
\hline 1721, Outubro 26 & $\begin{array}{l}\text { bando sobre o tesoureiro dos novos direitos restituir aos providos o que the } \\
\text { levou demais }\end{array}$ \\
\hline 1721, Novembro 23 & $\begin{array}{l}\text { bando para se abrir o caminho para as Minas de Cuiabá em direitura para o } \\
\text { Sertão }\end{array}$ \\
\hline 1722, Janeiro 12 & bando que se lançou para se não tirar ouro nem abrirem Minas no Paranaguá \\
\hline 1722, Fevereiro 5 & bando que se lançou para os negros não jogarem nesta cidade \\
\hline 1722, Fevereiro 17 & $\begin{array}{l}\text { bando que se mandou lançar na Villa do Rio São Francisco para se não tirar } \\
\text { ouro }\end{array}$ \\
\hline 1722, Março 1 & $\begin{array}{l}\text { bando sobre as companhias da ordenança e dos Auxiliares entrarem de guarda } \\
\text { as portas das Igrejas pelas endoenças. }\end{array}$ \\
\hline 1722, Março 18 & $\begin{array}{l}\text { bando para tirarem licença os que forem para Cuiabá e para não levarem sem } \\
\text { licença os índios das aldeias }\end{array}$ \\
\hline 1722, Março 27 & $\begin{array}{l}\text { bando para ninguém abrir caminho novo para as Minas do Cuiabá nem ir a } \\
\text { Vacaria. }\end{array}$ \\
\hline 1722, Março 28 & $\begin{array}{l}\text { bando para que ninguém vá faiscar as terras que estão por detrás da que cobre } \\
\text { a Marina e costa do Mar }\end{array}$ \\
\hline 1722, Abril 24 & bando que se lançou para os soldados que fugirem da Praça de Santos \\
\hline 1722, Maio 05 & $\begin{array}{l}\text { bando para que ninguém tenha em sua casa negros ou escravos fugidos e os } \\
\text { prenda logo }\end{array}$ \\
\hline 1722, Maio 12 & $\begin{array}{l}\text { bando para que os forasteiros que vierem a esta cidade e quiserem passar para } \\
\text { Cuiabá venham à presença do general }\end{array}$ \\
\hline 1722, Junho 14 & bando sobre se proibir nesta cidade que não haja jogos de parar \\
\hline 1722, Julho 15 & bando sobre o gado vacum que nesta capitania se furta e mata \\
\hline 1722, Julho 31 & bando sobre se poder usar de armas de fogo, curtas e compridas \\
\hline
\end{tabular}




\begin{tabular}{|c|c|}
\hline 1722, Setembro 13 & bando para não haver atravessadores de farinha nesta cidade \\
\hline 1722, Setembro 15 & $\begin{array}{l}\text { bando que se mandou lançar para que todas as pessoas providas de postos } \\
\text { de guerra, ordenanças, e auxiliares, e em ofícios de justiça, e da fazenda } \\
\text { apresentem suas patentes e profissões na Secretaria deste Governo. }\end{array}$ \\
\hline 1722, Setembro 16 & bando que se lançou sobre as armas \\
\hline 1722, Outubro 21 & $\begin{array}{l}\text { bando para que ninguém traga negro em sua companhia com a espada debaixo } \\
\text { do braço ou na mão }\end{array}$ \\
\hline 1722, Dezembro 31 & bando sobre se manifestar o ouro que vier das Minas Gerais na casa da oficina \\
\hline 1723, Fevereiro 02 & $\begin{array}{l}\text { bando para as pessoas que tiverem terras na estrada que vão para Santos } \\
\text { apresentarem os títulos }\end{array}$ \\
\hline 1723, Fevereiro 02 & $\begin{array}{l}\text { bando que se lançou para tirar passaporte as pessoas que embarcarem na Vila } \\
\text { de Santos }\end{array}$ \\
\hline 1723, Fevereiro 14 & $\begin{array}{l}\text { bando para não assistirem nesta capitania religiosos que não tiverem } \\
\text { conventual idade }\end{array}$ \\
\hline 1723, Março 07 & $\begin{array}{l}\text { bando para as companhias da ordenança e dos auxiliares entrarem de guarda as } \\
\text { portas das Igrejas }\end{array}$ \\
\hline 1723, Março 12 & bando sobre a proibição dos capuzes de capote metidos na cabeça \\
\hline 1723, Abril 11 & bando sobre as pessoas que houverem de ir para as novas Minas de Cuiabá \\
\hline 1723, Julho 02 & $\begin{array}{l}\text { bando sobre não passarem mulheres ao novo descobrimento das Minas de } \\
\text { Cuiabá }\end{array}$ \\
\hline 1723, Agosto 08 & $\begin{array}{l}\text { bando sobre os quintos do ouro que vierem das Minas de Cuiabá ou de outras } \\
\text { quaisquer }\end{array}$ \\
\hline 1723, Setembro 15 & $\begin{array}{l}\text { bando que se lançou na Vila de Itu e Sorocaba para acudirem todos para } \\
\text { prenderem ou matarem Lourenço Leme da Silva e João Leme da Silva }\end{array}$ \\
\hline 1723, Setembro 23 & $\begin{array}{l}\text { bando que se mandou lançar nas Minas de Cuiabá para prenderem ou matarem } \\
\text { os dois Régulos Lourenço e João Leme da Silva e se sequestrarem seus bens }\end{array}$ \\
\hline \multicolumn{2}{|r|}{ Volume XIII } \\
\hline Datação & Temática \\
\hline 1723, Outubro 19 & bando para se pagarem os quintos do ouro nesta cidade \\
\hline 1723, Novembro 01 & $\begin{array}{l}\text { bando sobre se fundir e embarretar o outro em pó que vier das minas nesta } \\
\text { Capitania }\end{array}$ \\
\hline 1723, Dezembro 03 & $\begin{array}{l}\text { bando sobre os soldados que assistirem nesta cidade não tomarem nada sem o } \\
\text { pagarem }\end{array}$ \\
\hline 1724, Fevereiro 20 & bando para os forasteiros virem a presença do General \\
\hline 1724, Março 29 & $\begin{array}{l}\text { bando que se lançou para não entrarem negros nesta cidade sem serem } \\
\text { visitados pela saúde }\end{array}$ \\
\hline 1724, Abril 15 & $\begin{array}{l}\text { bando que se lançou nesta cidade sobre a ponte em que se hão de curar os } \\
\text { bexiguentos }\end{array}$ \\
\hline 1724, Abril 30 & bando para partirem as tropas para as Minas de Cuiabá dia de São João \\
\hline
\end{tabular}




\begin{tabular}{|c|c|}
\hline 1724, Junho 25 & bando que se lançou nesta cidade, e nas Vilas de Itu e Sorocaba \\
\hline 1724, Agosto 8 & $\begin{array}{l}\text { bando que se lançou para as luminárias pelo nascimento do sereníssimo Senhor } \\
\text { Infante Dom Alexandre }\end{array}$ \\
\hline 1724, Agosto 15 & $\begin{array}{l}\text { bando sobre se pagarem os quintos do ouro e se fundir em barras e se marcarem } \\
\text { com as armas reais }\end{array}$ \\
\hline 1724, Agosto 21 & bando para se registrar o ouro que vier de Minas Gerais na Vila de Guaratinguetá \\
\hline 1724, Dezembro 28 & $\begin{array}{l}\text { bando sobre as pessoas que vierem das Minas Gerais para as do Cuiabá } \\
\text { apresentarem passaporte }\end{array}$ \\
\hline 1725, Março 17 & $\begin{array}{l}\text { bando que se lançou para que os índios e índias que não tiverem administrador } \\
\text { vão para as aldeias }\end{array}$ \\
\hline 1725, Março 19 & bando que se lançou sobre o ouro das Minas de Cuiabá que se tem quintado \\
\hline 1725, Abril 01 & bando sobre o socorro que se manda ao Sertão de Guaiases \\
\hline 1725, Maio 13 & bando para quem for para Cuiabá \\
\hline 1725, Maio 25 & bando que se lançou para partirem as tropas para Cuiabá e se despacharem \\
\hline 1725, Junho 04 & bando sobre sal que há de repartir com os moradores desta cidade e sua comarca \\
\hline 1725, Agosto 11 & $\begin{array}{l}\text { bando que se lançou nas Vila de Itu, Sorocaba e Parnaíba sobre o que levarão } \\
\text { os oficiais que foram a cobrança dos quintos reais do ouro que veio de Cuiabá }\end{array}$ \\
\hline 1725, Setembro 03 & bando sobre os bexiguentos desta cidade \\
\hline 1725, Outubro 08 & bando sobre se poder mandar gados para as Minas de Cuiabá e levar da Vacaria \\
\hline 1725, Novembro 30 & $\begin{array}{l}\text { bando para os forasteiros virem declarar para que Minas querem ir, de Cuiabá } \\
\text { ou Guayazes. }\end{array}$ \\
\hline 1726, Março 03 & $\begin{array}{l}\text { bando sobre tirarem despacho as pessoas que forem para Cuiabá e não irem } \\
\text { mulheres de suspeita }\end{array}$ \\
\hline 1726, Março 17 & $\begin{array}{l}\text { bando sobre não partirem ninguém para Cuiabá primeiro que o General na } \\
\text { monção presente }\end{array}$ \\
\hline 1726, Abril 09 & $\begin{array}{l}\text { bando para partirem as tropas para as Minas de Cuiabá sem embargo do bando } \\
\text { acima }\end{array}$ \\
\hline 1726, Abril 21 & $\begin{array}{l}\text { bando sobre os índios e índias que se acharem fora de seus administradores } \\
\text { apresentarem os despachos }\end{array}$ \\
\hline 1726, Abril 24 & $\begin{array}{l}\text { bando sobre os forasteiros que estiverem nesta cidade para irem a Cuiabá virem } \\
\text { a esta secretaria }\end{array}$ \\
\hline 1726, Maio 05 & $\begin{array}{l}\text { bando sobre os serventuários dos oficiais não pagarem a terça parte de seu } \\
\text { rendimento }\end{array}$ \\
\hline 1726, Maio 19 & $\begin{array}{l}\text { bando para as pessoas que tiverem terra no caminho que vai de Jundiaí para os } \\
\text { Guaiases apresentem os títulos }\end{array}$ \\
\hline 1726, Junho 19 & bando que se lançou sobre os Carijós e bastardos que se livrarem da administração \\
\hline 1726, Dezembro 02 & $\begin{array}{l}\text { bando que se lançou nestas Minas sobre os negros não venderem ouro e se lhe } \\
\text { não poder comprar }\end{array}$ \\
\hline 1727, Janeiro 01 & bando sobre os negros fugidos e se açoitarem os que forem rebeldes \\
\hline
\end{tabular}




\begin{tabular}{|c|c|}
\hline 1727, Janeiro 01 & bando sobre os bastardos e índios se conservarem com seus administradores \\
\hline 1727, Janeiro 10 & $\begin{array}{l}\text { bando sobre se não fazerem execuções de dividas particulares em quanto se } \\
\text { cobram os reais quintos }\end{array}$ \\
\hline 1727, Janeiro 18 & $\begin{array}{l}\text { bando para ninguém ir ao rio dos perrudos ao gentio sem entrar Antonio Borralho } \\
\text { primeiro }\end{array}$ \\
\hline 1727, Janeiro 22 & bando para não irem negras de tabuleiro vender mantimentos as Lavras, etc \\
\hline 1727, Janeiro 22 & bando para se não darem tiros de monte \\
\hline 1727, Janeiro 25 & $\begin{array}{l}\text { bando para não estarem negras forras e escravos em Tavernas e ranchos sem os } \\
\text { Senhores ou brancos }\end{array}$ \\
\hline 1727, Fevereiro 22 & $\begin{array}{l}\text { bando sobre as pessoas que pagassem quintos demais das Lagos os tornarem } \\
\text { a cobrar }\end{array}$ \\
\hline 1727, Fevereiro 23 & bando sobre tirar licença nesta secretaria quem quiser ir para povoado \\
\hline 1727, Fevereiro 29 & bando sobre os ourives de ouro destas Minas fecharem as tendas e não trabalharem \\
\hline 1727, Março 07 & bando sobre os descobrimentos de ouro \\
\hline 1727, Abril 13 & bando sobre se fazerem descobrimentos de ouro \\
\hline 1727, Maio 07 & $\begin{array}{l}\text { bando sobre os contratadores dos dízimos não cobrarem as suas dívidas } \\
\text { executivamente e só os dízimos }\end{array}$ \\
\hline 1727, Setembro 15 & bando sobre as penas que se impõem aos que jogarem nesta minas jogos de parar \\
\hline 1727, Setembro 18 & $\begin{array}{l}\text { bando sobre os negros e negras não irem vender as lavras e não haverem fornos } \\
\text { fora da Vila }\end{array}$ \\
\hline 1727, Dezembro 12 & bando sobre se não venderem nesta Capitania os índios que vierem do Sertão \\
\hline 1727, Dezembro 14 & $\begin{array}{l}\text { bando sobre os negros não usarem de armas proibidas de porretes e capotes } \\
\text { nesta minas }\end{array}$ \\
\hline 1727, Dezembro 28 & $\begin{array}{l}\text { bando sobre os índios assistirem em casas de seus administradores e irem para } \\
\text { as aldeias }\end{array}$ \\
\hline 1728, Janeiro 05 & bando sobre os escravos destas minas \\
\hline \multicolumn{2}{|r|}{ Volume 32} \\
\hline Datação & Temática \\
\hline 1724, Abril 28 & bando relativo aos irmãos Lemes \\
\hline 1724, Abril 29 & bando referente aos irmãos Lemes \\
\hline
\end{tabular}

\section{Análise das assinaturas e tipo de letra dos documentos - a questão da autoria}

Todo pesquisador interessado no contexto colonial setecentista e que tem em seus objetivos o estudo do governo de Rodrigo Cesar de Menezes e a escrita do período depara primeiramente com o conjunto de publicações do Arquivo Público do Estado de São Paulo intitulado 
Documentos Interessantes, especificamente os volumes XII, XIII, XX e XXXII, ou então documentos avulsos localizados em instituições públicas e privadas brasileiras e portuguesas, entre as quais está o Arquivo Histórico Ultramarino, onde se encontra grande parte da correspondência produzida no Brasil Colonial. O desafio passa por dois caminhos: primeiro, verificar a relação de fidedignidade entre a versão impressa do Arquivo com o original manuscrito, uma vez que há muitos casos de lição deturpada. Segundo, e mais coerente, seria a busca pelas fontes primárias, ou seja, os originais manuscritos produzidos pelo punho ou pelo menos pela supervisão de Rodrigo Cesar de Menezes, atividade que implicaria ter domínio filológico e paleográfico para a sua leitura e transcrição.

A publicação do APESP atribui a autoria documental a Rodrigo Cesar de Menezes. Citações como correspondência do Rodrigo Cesar de Menezes ou documentos do governador são muito comuns nesse tipo de publicação. Embora não haja dúvida da autoria intelectual por parte do governador, essa situação adquire determinada complexidade à medida que se lê o documento impresso e verifica-se que há destaque para o nome de Menezes, aparecendo esse, na maioria das vezes, em itálico, como se valesse como assinatura. Esse fato pode levar a equívocos de atribuição de autoria e relações falhas quanto aos dados linguísticos encontrados, principalmente quanto à caracterização da prática de escrita em questão, relacionando-a à do governador e à sua história "escolar" e não ao seu próprio produtor material, de um outro estrato social e histórico, no caso o seu secretário.

Ao voltar os olhos para os documentos manuscritos, verifica-se que o itálico dado ao nome do governador, na versão impressa, resulta de escolha subjetiva do editor, pois não há diferença gráfica entre a letra que compõe a mancha do documento e a utilizada na assinatura, levando a acreditar que se trata de um conjunto de cópias, principalmente por estarem reunidos em um único livro de registros, lembrando uma espécie de cartulário. Ou, então, seria a versão impressa realizada com base em outra documentação manuscrita, cuja relação, até o momento, não se alcançou.

No contexto de produção desses documentos, como já mencionado, não há como negar a responsabilidade de Rodrigo Cesar de Menezes como autor intelectual de toda a documentação. Como governador e capitão general, era responsável pela administração da capitania de São Paulo e, como se sabe, essa atividade, muitas vezes, era realizada por meio da escrita. A análise das assinaturas e do tipo de letra dos bandos possibilita a verificação desse fato por encontrar seu nome ou a indicação do seu nome em quase todos os documentos. 
Do ponto de vista material, a responsabilidade estava relacionada com outros cargos, principalmente o de secretário do governo, sob a figura de Gervasio Leyte Rebello.

FIGURA 3 - Trecho retirado do bando da versão publicada pelo Arquivo Público do Estado de São Paulo

\section{Secretario do Gov. ${ }^{\circ}$ Gervasio Leyte Rebello a fez.}

Fonte: APESP, 1901.

Esses dados, no entanto, não são suficientes para esgotar a questão autoral da documentação em questão. Pode-se pensar também, pelo número de produções da secretaria da capitania em geral, que poderia haver outros profissionais da escrita responsáveis por essa função, como, por exemplo, escrivães e tabeliães, cargos relacionados em Salgado (1985) à prática de escrita administrativa colonial. Essa hipótese parte de indicações à margem de determinados documentos com a letra diferente da utilizada ao longo do livro de registro. Nestes trechos, retirados do manuscrito que se refere aos soldados fugitivos, cuja transcrição se encontra neste artigo, pode-se verificar uma diferença nas assinaturas em relação ao traçado do "R" na palavra "Rebello". À esquerda, a escrita da margem; à direita, a do documento.

FIGURA 4 - Trechos de bando sobre soldados fugitivos, presentes no volume XII dos Documentos Interessantes
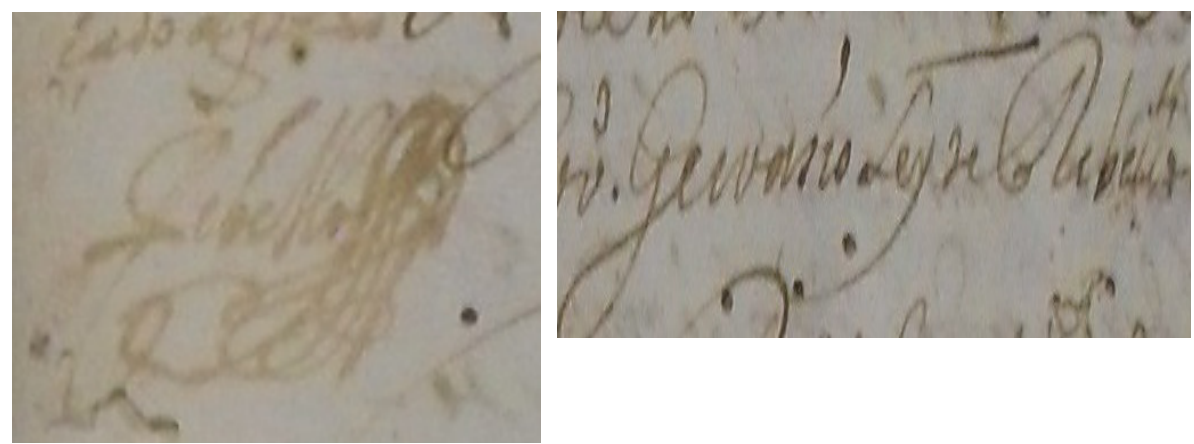

Fonte: APESP, 1901, p. 9.

O estudo constatou, portanto, que a documentação manuscrita dos bandos, com exceção das escritas marginais, tem apenas um tipo de letra, a mesma utilizada no registro da assinatura do governador. Por estar presente 
em livro de registro de secretaria, o punho nesse material apresenta algumas oscilações, provavelmente próprias do processo de cópia, além da variação gráfica proveniente do seu autor material original. Já na publicação do APESP, a assinatura de Menezes, na edição dos bandos, apresenta-se sempre em itálico, com destaque. Pelo que foi verificado, o esforço material empregado na composição documental estava, em grande parte, a cargo do secretário Gervasio Leyte Rebello, com autoria apenas intelectual de Rodrigo Cesar de Menezes, sem a possibilidade de se verificar como se realizava a supervisão dessa produção.

\section{A escrita dos bandos}

Com apenas um escriba como autor material reconhecido, o secretário Gervasio Leyte Rebello ${ }^{3}$ (outros ainda precisam ser estudados), o esperado seria uma prática de escrita com poucas oscilações, com escolhas gráficas sem muitas alternâncias, apenas com hábitos de escrita particulares ao conhecimento da língua portuguesa do secretário e da sua prática de escrita profissional. Embora fossem comuns as variações no mesmo punho à época, não se pode descartar a hipótese de que o fato de haver dois autores nesse caso, o autor material, na figura de Rebello, e o intelectual, na do governador Menezes, pode ter influência na escrita dos manuscritos e, portanto, no estado de língua testemunhado. A análise apresentou os seguintes resultados quanto à escrita do corpus:

a) Duplicação do $<1>$ : há alternância na escrita de palavras que apresentem $<1>$ na posição medial. Às vezes, elas são grafadas com apenas um $<1>$; às vezes, a mesma palavra é grafada com o $<11>$ duplo. Como por exemplo, a palavra "alegrar". Nos anos de 1721, 1722, 1724 (v. XIII), ela aparece com o <1l> duplo: allegrar. Entretanto, nos anos de 1726 e 1724 (v. XXXII), aparece com um $<\mathrm{l}>$ apenas: alegrar e alegres, respectivamente. No ano de 1728, só foram registradas palavras com o uso do $<11>$ duplo, como ocorre em: alleguem, pellas, nellas, villa;

\footnotetext{
${ }^{3}$ A confirmação do punho do secretário foi estabelecida com o cotejo de cartas escritas por Gervásio Leyte Rebello, localizadas no Arquivo Histórico Ultramarino, em Lisboa, pertencentes ao Catálogo do Projeto Resgate "Barão do Rio Branco". Para mais informações, consultar Fachin (2014).
} 
b) alternância de $<\mathrm{i}>\mathrm{e}<\mathrm{y}>$ : uma mesma palavra pode ser escrita com $<\mathrm{i}>$, com $<\mathrm{y}>$, ambos em posição medial. Como ocorre com o nome: Silva. Nos anos de 1723 e 1724 (v. XXXII) o nome foi escrito com $<\mathrm{i}>$ : Silva. Já no ano de 1725, ele foi escrito com $<\mathrm{y}>$ : Sylva. O mesmo ocorreu com a palavra: debaixo. Em 1724 (v. XXXII), foi grafado usando o fonema $<\mathrm{i}>$ : debaixo. Entretanto, em 1727, a mesma palavra foi registrada com $\langle\mathrm{y}\rangle$ : debayxo. Outras palavras grafadas com $<\mathrm{y}>$ foram: leyte $(1721,1722,1723,1724-\mathrm{v}$. XIII1725, 1726, 1727 e 1728); Cuyaba (1723, 1724, 1727,1728); mayor (1727); alheyos (1728), arrayal (1724 - v. XXXII). Foi encontrado apenas um caso de uso do $<\mathrm{y}>$ em posição final: mandey (1727);

c) alternância de $\langle$ e $>$ e $<\mathrm{i}>$ : quando se refere ao uso do $<$ e $>$ e do $<\mathrm{i}>$, pode-se observar predominância pelo uso do $<\mathrm{e}>$. Veja os exemplos: admetido, officiaes, demenutas (1721); destricto, ouvedoria (1722), quaesquer, demenutas (1723), delligencia (1725), destricto (1726), officiaes, admenistrado (1728). Registros de palavras com $<\mathrm{i}>$ : primeiras (1722), mineiros, principal, impostas (1723), impedimento (1726);

d) duplicação do $\langle\mathrm{f}>$ : são estes alguns dos casos de duplicação: officiaes (1721), efficas (1723), officiaes, refferidas (1728);

e) duplicação do $<\mathrm{n}>$ : a duplicação só ocorreu em palavras com final “-ano". Como em: anno (1724, 1725, 1726,1728), annos (1724, v. XXXII) e danno (1728). Outras palavras com "n" foram grafadas com apenas um. Como ocorre em: minas, bando, grande (1724), continuando, destinava (1725), penas, diante, mando (1728) e bando (1724, v. XXXII);

f) alternância de $<\mathrm{s}>\mathrm{e}<\mathrm{Z}>$ : neste caso, também ocorre de uma mesma palavra ser grafada com $<\mathrm{s}>\mathrm{e}<\mathrm{z}>$. São os casos das palavras: fez, mês e casa. $\mathrm{O}$ verbo é grafado com $<\mathrm{z}>$ no bando correspondente ao ano de 1721. Mas nos outros anos, ele é grafado com $<$ s $>$ : fes. O substantivo "mês" é grafado com $<\mathrm{s}>$ no bando correspondente ao ano de 1724, mas nos bandos correspondentes aos anos de 1722, 1727 e 1728, tal substantivo é grafado com $<\mathrm{z}>$ : mez, mezes, mezes. O mesmo processo se dá com o substantivo "casa". No bando correspondente ao ano de 1721, ele é escrito com $<$ s $>$ : casa. Entretanto, nos bandos correspondentes aos anos de 1723, 1727 
e 1728, encontra-se o registro deste substantivo com a letra $<\mathrm{z}>$ : caza e cazas. Outras palavras grafadas com $<\mathrm{z}>$ encontradas foram: cauza, auzente, dezerção (1721), razões, fazendo, preza (1722), prezumir, dezemcaminhão, dezembarcar, dezejava, prezente (1723), prezença (1724), rezoluto (1725), cazados, preza, prezente (1726), prezos (1727), couza, auzentarem, prezumir, prezos (1728). Outras palavras encontradas grafadas com $<\mathrm{s}>$ foram: caso (1721), mais (1722, 1723, 1724, 1725), efficas (1723), tres (1724, 1726);

g) alternância de $<\mathrm{s}>\mathrm{e}<\mathrm{c}>$ : há predominância de registro de palavras grafadas com <ç>. Exemplos: praça, serviço (1721), conservação, condição, lançar, praça (1722), lançar, cobrança, lançado (1723), praça, monção, prezença (1724, v. XIII), monição, praça, lançar, serviço (1725), praça, monção, fação, petição (1726), praça, roças, lançar (1727), lançou, segurança, roças, lançar (1728), lançou, lançar, Março (1724, v. XXXII). Aqui também ocorre o caso de uma mesma palavra ser grafada com $<\mathrm{s}>\mathrm{e}<\mathrm{c}>$, como ocorre no caso da palavra: terça. No bando correspondente ao ano de 1726, tal palavra é grafada com $<c ̧>$ : terça. Entretanto, no bando correspondente ao ano de 1727, esta mesma palavra é grafada com $<\mathrm{s}>$ : tersa. Outras palavras grafadas com $<$ s $>$ são encontradas no bando de 1727 , asoutes e, no de 1728, consentisse e observância;

h) uso de $<x>$ : O uso do $<x>$ é basicamente igual ao uso atual, portanto sem casos de oscilação com $<\mathrm{s}>$ ou outros elementos. Exemplos: fixaraõ (1721), fixara, fixandosse (1722), fixara (1723, 1724, 1725,1726, 1727, 1728), fixou (1724, v. XXXII), trouxessem (1723), próxima (1724), experimentaõ (1728);

i) alternância de $<\mathrm{s}>\mathrm{e}<\mathrm{ss}>$ : novamente ocorre o caso de uma mesma palavra ser grafada com $<_{\mathrm{S}}>\mathrm{e}<\mathrm{sS}>$. É o caso da palavra: assim. Grafada com os dois "s" nos bandos correspondentes aos anos de 1721, 1724,1725. É grafada com um "s" só no ano de 1728: asim. Outras grafadas com $<$ ss $>$ : possão $(1721,1722,1724$, v. XIII, 1728), pessoa, fixandosse (1722), pessoa, passagem, pagassem, assistisse, trouxessem, quintassem (1723), assistirem, passada (1724), pessoas, passarão (1725), sessenta, pessoas, passão (1726), consistisse, passou, mandassem, devessem (1728). Como se pode ver, os verbos no tempo Pretérito Imperfeito, no modo Subjuntivo, são grafados com $<$ ss $>$ assim como se faz de acordo com o português atual; 
j) uso de $<\mathrm{c}>$ e $<$ ç $>$ : é basicamente o mesmo que se usa atualmente. Veja os exemplos com $<c ̧>$ : segurança, faça, licença (1721), conceição (1728). Agora, exemplos com $<\mathrm{c}>$ : denunciar, noticia, ignorancia, licença (1721), falecer, ignorancia, principais (1723), procedera, parecer, ignorancia (1724), ignorancia (1726), consideravel (1727), ignorancia, observancia, conceição (1728);

k) O uso do $\langle\mathrm{h}>$ : ao observar os bandos pode-se verificar o uso do "h" nos seguintes casos: hali, húa (1723), hir, hirem, ha (1725), prohibe, he (1726), húa, hum (1727) hum, sahir, prohibidas (1728). O verbo "haver" foi escrito com o $<\mathrm{h}>$ assim como se escreve de acordo com o português atual. Veja os exemplos: haverem (1725), havendo (1726), havendo, haverem (1727), haver, houve, havendo, houver (1728);

1) Troca de vogais: ao observar os bandos em questão, verifica-se uma troca de vogais. Esta pode ser entre $<\mathrm{i}>\left|\langle\mathrm{u}\rangle ;<_{\mathrm{o}}\right\rangle|<\mathrm{u}\rangle ;<\mathrm{e}>\mid<\mathrm{a}>\mathrm{e}$ $<\mathrm{e}>/<\mathrm{i}>$, como se mostrou anteriormente. Casos encontrados de $<\mathrm{i}>$ $\mathrm{e}<\mathrm{u}>$, há: outavas, asoutes (1727), noute, couza (1728). Casos de $<\mathrm{o}>\mathrm{e}<\mathrm{u}>$, temos: logar (1722), lugar (1723), monição, descuberto (1725). Como se pode ver, ocorrem casos de uma mesma palavra ser escrita com uma ou outra vogal, como ocorre em logar e lugar;

m) $\mathrm{O}$ uso do $<$ th $>$ : foram encontrados dois casos com uso de $<$ th $>$, ambos na palavra teor. Veja: theor $(1722,1725)$;

n) casos particulares: ao observar os bandos em questão, nota-se a ocorrência de casos particulares como: $<\mathrm{y}>\mathrm{e}<\mathrm{im}>-m y$ (1721), $<\mathrm{m}>\mathrm{e}<\sim>-$ nenhuã (1722), $<\mathrm{m}>\mathrm{e}<<^{\prime}>-$ algúas (1723), $<\mathrm{s}>\mathrm{e}$ $<\mathrm{c}>$ - conciderava (1723), $<\mathrm{v}>\mathrm{e}<\mathrm{b}>-$ sorocava $(1723),<\mathrm{m}>\mathrm{e}$ $<\mathrm{n}>$ - promptas (1725) e $<\mathrm{s}>\mathrm{e}<\mathrm{sc}>$ - recolhescem (1728);

o) outros casos: 1721 - acháo, continuam, prezestir, emcorrerâ, cincoenta; 1722 - detreminação, destricto; 1723 - emcorrerâ; 1724 (v. XIII) - menhãa, aribarão; 1724 (v. XXXII) - regulos, treslado; 1725 - polvra, promptas, socorrerse; 1726 - homê, destricto; 1727 - cadea, castigalos, darem-lhe; 1728 - cadea, emcorrerão;

p) pontuação: a vírgula, nos bandos selecionados para análise, é usada frequentemente. Seu uso varia tanto em contexto de vírgula quanto como ponto final e parece não seguir uma regra. Veja alguns 
exemplos: “Ordeno, e mando q' todas as pessoas, q' quiserem hir a elle fazer serviço a S.Mag. ${ }^{d e} q$ ' $D .{ }^{s} g .{ }^{e}$ se ponham promptas, $p . a$ irem para a tropa, que se há de expedir, ...”. (1725), “ordeno, q'todo o soldado q' se achar auzente, e se restituir a comp. ${ }^{a}$ em $q$. serviu dentro em trinta dias, será admetido, e perdoado, e quando o não faça será trancado nesta cid. ${ }^{e} p{ }^{a}{ }^{a}$ onde virâ remetido, e assim todo o q'daqui por adiante se auzentar ... "'(1721).

Quanto ao ponto final, não há praticamente seu uso nos bandos em questão. A vírgula, na maioria das vezes, toma seu papel e, por conta disso, não há períodos, e, sim, um grande parágrafo. Entretanto, ao final de quase todos os bandos usou-se o ponto final para encerrar o assunto. No bando correspondente ao ano de 1728, foi encontrado o ponto final no meio da correspondência, com a função de ponto no final de frase. Foi a única vez que se encontrou esse uso. Veja no trecho a seguir: “... e me constar q' não houve a devida observância. Ordeno e mando q' daqui em diante...". No mesmo bando, encontra-se no trecho "... officiaes de justiça. ou guerra..." o ponto final sendo usado no lugar da vírgula. Por conta da escassez do uso do ponto final, a leitura dos bandos se torna mais complicada.

Em bandos datados com os anos de 1721,1722, 1723, 1728, observa-se o uso dos dois pontos (:). Nos três primeiros anos, os dois pontos foram usados antes da palavra "ordeno". Exemplo: “... no serviço de S.Mag. de. ordeno q' todo soldado..." (1721). De acordo com a gramática do português culto do Brasil, os dois pontos deveriam vir depois da palavra "ordeno" e não antes. No bando do ano de 1728, esta pontuação foi usada no trecho: “...por outro bando, q'já se lançou: e p. ${ }^{a} q$ 'chegue a noticia de todos...”.

A última pontuação encontrada nos bandos separados para análise foi o ponto e vírgula (;). Seu uso aparece nos correspondentes aos anos de 1721, 1722, 1725 e 1726. Veja um exemplo: “... perdendo soldados veteranos; e metendo nellas em seu lugar...” (1721). Nesse trecho, seu uso ocorreu no lugar da vírgula;

r) uso de maiúsculas:

No início de parágrafo: em todos os bandos selecionados para análise, ocorreu o uso de letra maiúscula nessa posição. 
Datas oficiais: "S. Paulo aos 18 de Setr. ${ }^{\circ}$ de 1721", "Villa Real do Bom Jesus do Cuyabâ aos cinco de Janr.o Anno de 1728".

Títulos: S.Magde, Gov. ${ }^{\text {or }}$, Gov. ${ }^{\circ}(1721)$, Sarg. ${ }^{\text {to }}$ Mor, Prov. ${ }^{\text {r }}$ (1723), Capp. $^{m}$ (1725), Capp. ${ }^{\text {es }}$ Mores (1726), Senhores (1727), S. res, S. ${ }^{r}(1728)$, Guarda Mór, Mestre de Campo, Ex. ${ }^{\text {mo }}$ S. ${ }^{r}$, Cap. ${ }^{m}$ General (1724, v. XXXII). Entretanto, no bando correspondente ao ano de 1722, o título "Oficiais da Câmara" aparece em letra minúscula: off. ${ }^{e s}$ da Camr. ${ }^{a}$.

Nome próprio: Rodrigo Cesar de Menezes (1721, 1722, 1724, v. XXXII), $R .^{\circ}$ Cesar de Menezes (nos demais anos), Santos, (1721), Minas (1722), Rio, Cuyaba, Sorocava, Silva Monteiro, Minas, João Miz' Claro (1723), Cuyaba (1724, v. XII), Bueno da Sylva, Certtão dos Guayazes (1725), Cuyaba, Nova Colonia, Março, São Paulo (1726), Minas (1727), Lavras de Ribeirão (1728), Balthazar Ribeiro, Março, Minas Alegres (1724, v. XXXII). Entretanto, no bando de 1723 , ocorre do nome próprio "Sorocaba" ser grafado com minúscula: sorocava. E, no bando correspondente ao ano de 1724, aparece: Rio grande, com apenas o primeiro nome em maiúscula.

Logradouros públicos: na maioria dos bandos selecionados para análise, ocorreu a utilização da letra maiúscula quando se tratava de nomes de logradouros públicos. Veja os exemplos: Barra (1721), Villa de Pernangóa (1722), Villa de Ontû, Villas de Santos (1723), Villas (1725), Villas (1726), Villa, Villa do Real do Bom Jesus do Cuyabá (1727), Villa (1728).

Outras ocorrências: A letra maiúscula é usada em algumas situações de meio de frase. Exemplos: “...assim todo o q'daqui por diante se auzentar sem Licença dos seus officiaes..." (1721), “...na paragem mais publica do dito Arrayal, e por passar o referido na verdade...", o mesmo arraial é grafado em minúscula algumas linhas antes deste trecho citado acima ("...o qual se lançou neste arrayal a som..."); 
s) abreviaturas: encontram-se quatro tipos no corpus. Levando-se em consideração a classificação de Costa (2006): 1) abreviação por sinal geral, composta de um signo abreviativo, no caso dos bandos, por apóstrofo ('), indicando a falta de uma ou mais letras. Esse tipo ocorre, por exemplo, em $q^{\prime}=$ que (presente em todos os bandos em questão, exceção feita ao bando correspondente ao ano de 1724, v. XXXII) e Porq' = Porque (1726 e 1727); 2) abreviação por contração ou síncope, definida pela supressão de letras no interior da palavra, como em $r s=$ reis (1721 e 1726); 3) abreviação por suspensão ou apócope, por meio da supressão de elementos finais da palavra: q. = que (1721); 4) abreviação por letra sobreposta, constituída pela sobreposição de uma ou mais letras que compõem a parte suprimida da palavra. Esse tipo de abreviação está presente em todos os bandos selecionados para análise, sem exceção. Veja alguns exemplos: $m^{t o}=$ muito; continuam. ${ }^{t e}=$ continuamente; $L{ }^{o s}=$ Livros (1721), Capp. $^{\text {nias }}=$ Capitanias; qualq. ${ }^{r}=$ qualquer; Mag. ${ }^{d e}=$ Magestade (1722), Outr. ${ }^{o}=$ Outubro; $q \cdot^{\text {tos }}=$ quantos (1723), Gov. $^{\circ}=$ Governo; Fevr $^{o}=$ Fevereiro $\left(1724\right.$, v. XII), descobrim. ${ }^{\text {to }}=$ descobrimento; Primr $^{\circ}=$ Primeiro (1725), Prez $.{ }^{\text {te }}=$ Prezente; $r e g .{ }^{\text {to }}=$ regimento (1726), Janr $^{\circ}=$ Janeiro (1727), S. ${ }^{\text {res }}=$ Senhores; Capp . ${ }^{e s}=$ Capitães (1728), Ex. ${ }^{m o}=$ Excelentíssimo; $S{ }^{r}=$ Senhor $(1724$, v. XXXII);

t) acentuação: encontraram-se três tipos de acentuação ao analisar os bandos em questão. São eles: til ( $\sim)$, acento agudo (') e acento circunflexo $\left({ }^{\wedge}\right)$. Seus usos são às vezes distintos do sistema atual em relação aos acentos agudo e circunflexo. Quanto ao til, seu uso é basicamente o mesmo em relação ao sistema atual. No caso do agudo, os exemplos aparecem em contexto de til ( ): acháo, registrará, estáo (1721), nenhúa, pubicará (1722), húa (1723), atenderá, dará, publicará, fixará (1725), húa (1727), terá, será, publicará, fixará (1728). Veja os exemplos de acento circunflexo $\left(^{\wedge}\right)$ : serâ, publicarâ, mandarâ (1721), registrarâ, serâ, passarâ, publicarâ (1722), Ontû, Cuyabâ (1723), Cuyabâ, publicarâ, procederâ, fixarâ (1724, v. XIII), Cuyabâ, homês (1726), Cuyabâ, dê (1728). Veja os exemplos de til ( ): certidaõ, dezerçaõ (1721),

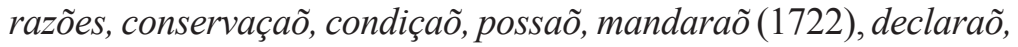

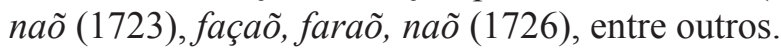


Dado o exposto, pode-se perceber que os acentos agudo e circunflexo se confundem. Ora uma mesma palavra é grafada com o acento agudo, ora com o circunflexo. É o que ocorre, por exemplo, em: publicará e publicarâ. Ambos os acentos foram usados para marcar a sílaba tônica da palavra. O mesmo ocorre com a palavra "será", ora grafada com um acento, ora grafada com outro.

\section{Conclusão}

Embora a publicação do Arquivo Público do Estado de São Paulo traga em seu título a atribuição autoral a Rodrigo Cesar de Menezes dos diversos documentos editados, e isso se refira a uma prática comum na administração colonial, ou seja, a autoridade superior normalmente não era o responsável material pela composição documental, a análise do corpus demonstrou que é necessária a diferenciação entre autoria material e autoria intelectual. A implicação dessa necessidade se dá por duas razões: primeiro, por destacar que os hábitos gráficos dos documentos podem pertencer, em diferentes níveis, ao governador e ao seu secretário, Gervasio Leyte Rebello, ambos provavelmente com histórias de vida e de contato linguístico díspares; segundo, por talvez representar uma prática de escrita pertencente a uma tradição administrativa mais antiga, não pertencente nem ao governador nem ao secretário, mas às exigências diplomáticas da própria espécie documental em questão, como se o documento, na sua composição, exigisse o uso de certos hábitos de escrita, além das fórmulas utilizadas ao longo do texto, no protocolo inicial e final, fator que ainda precisa compor o objeto de estudo de muitas pesquisas filológicas.

Nesse contexto, apesar da estrutura fixa - por se tratar de documento diplomático - verificada em todos os testemunhos, há diversos casos de variação gráfica. Trata-se de um estado de língua que, para ser registrado, oferecia dúvida até para um profissional da escrita de tão larga experiência como o secretário Gervasio Leyte Rebello. Com uma escrita alternante, resultado da mescla de hábitos gráficos do escriba com o que escrevia de ouvido ou por meio de cópia, transmitido pelo autor intelectual dos documentos, é fundamental a identificação detalhada de como se operacionalizava esse processo. 
No governo de Menezes, as ordens do cotidiano, os bandos, por exemplo, assim como todos os trâmites de escrita, emanavam diretamente da figura do governador e capitão general, materialmente compostos em sua maioria pelo seu secretário. Em estudos posteriores, pode-se chegar a um quadro sistematizado das variações encontradas, classificadas e categorizadas, que podem demonstrar o estado de uso da língua portuguesa numa tradição administrativa que, embora com estruturas fixas, poderia apresentar também formas livres, muito dependentes do grau de conhecimento linguístico do escriba em questão e independentes do tipo de documento. Esse tipo de resultado pode contribuir significativamente com os trabalhos filológicos e de linguística histórica, já que, entre as suas preocupações, está a identificação de testemunhos fidedignos, genuínos, autênticos e de como efetivamente a língua portuguesa era utilizada. Nesse sentido, será de suma importância o cotejo com diferentes documentos, sob responsabilidade de Menezes, e bandos pertencentes a outros governadores de capitania, para ampliar o conhecimento a esse respeito.

\section{Referências}

BELLOTTO, H. L. Como fazer análise diplomática e análise tipológica de documento de arquivo. Projeto como fazer. São Paulo: Arquivo do Estado e Imprensa Oficial do Estado, 2002. v. 8.

CASTRO, I. A primitiva produção escrita em português. In: CATÓN, José María Fernández (Dir.).Orígenes de las lenguas romances en el Reino de León. Siglos IX-XII. León: Centro de Estudios e Investigación San Isidoro, 2004. (Collección Fuentes y Estudios de Historia Leonesa, 104. v. II, p. 69-97)

COSTA, R. F. Abreviaturas: simplificação ou complexidade da escrita? Histórica, São Paulo, v. 1, n.15, 2006. Disponível em: <http://www. historica.arquivoestado.sp.gov.br/materias/anteriores/edicao15/ materia01/>. Acesso em: 2 jan. 2017.

DOCUMENTOS Interessantes para a História e Costumes de S. Paulo: Bandos e Portarias de Rodrigo Cesar de Menezes. Arquivo Público do Estado de São Paulo (APESP). São Paulo: Escolha Typographica Salesiana, 1901. v. XII. 
DOCUMENTOS Interessantes para a História e Costumes de S. Paulo: Bandos e Portarias de Rodrigo Cesar de Menezes. Arquivo Público do Estado de São Paulo (APESP). São Paulo: Typographia Aurora, 1895. v. XIII.

DOCUMENTOS Interessantes para a História e Costumes de S. Paulo: Correspondência interna do Governador Rodrigo Cesar de Menezes 1721-1728. Arquivo Público do Estado de São Paulo (APESP). São Paulo: Typographia Aurora, 1896. v. XX.

DOCUMENTOS Interessantes para a História e Costumes de S. Paulo: Correspondências e Papéis Avulsos de Rodrigo Cesar de Menezes 17211728. Arquivo Público do Estado de São Paulo (APESP). São Paulo: Typographia Andrade \& Mello, 1901. v. XXXII.

FACHIN, P. R. M. "Escreve quem sabe e assina quem pode": produção e circulação de manuscritos no Brasil colonial. Revista da Anpoll, Anpoll, v. 1, n. 37, p. 213-232, 2014. Doi: https://doi.org/10.18309/anp.v1i37.781. LUÍS, W. Governo de São Paulo - Capitania de Rodrigo Cesar de Menezes. São Paulo: Casa Garrauz, 1918.

MEGALE, H. Pesquisa filológica: os trabalhos da tradição e os novos trabalhos em língua portuguesa. In: SEMINÁRIO DO GRUPO DE ESTUDOS LINGÜÍSTICOS DO ESTADO DE SÃO PAULO (GEL), XXVII., 1998, Campinas. Estudos Lingüísticos, Campinas: Editora da UNICAMP, 1998. v. 1. p. 3-28.

SALGADO, G. (Org.). Fiscais e Meirinhos - Administração no Brasil Colonial. Rio de Janeiro: Nova Fronteira, 1985.

SPINA, S. Introdução à edótica: crítica textual. 2. ed. rev. e atual. São Paulo: Ars Poetica/ Edusp, 1994. 